\title{
Pengembangan Media Pembelajaran Blabak Trarerodi pada Materi Geometri Transformasi: Tahap Expert Review
}

\author{
Kharisma Lisa Hada \\ Institut Agama Islam Negeri Kediri, Kediri, Indonesia \\ kharismalisahada185@gmail.com \\ Fitriana Ika Maulida \\ Institut Agama Islam Negeri Kediri, Kediri, Indonesia \\ fitriana.ika.maulida@gmail.com \\ Aisyah Susmita Dewi \\ Institut Agama Islam Negeri Kediri, Kediri, Indonesia \\ aisyahsd561@gmail.com \\ Checylya Kharisma Dewanti \\ Institut Agama Islam Negeri Kediri, Kediri, Indonesia \\ checylya421512ipa5@gmail.com \\ Agus Miftakus Surur \\ Institut Agama Islam Negeri Kediri, Kediri, Indonesia \\ surur.math@gmail.com
}

\begin{abstract}
Abstrak
Pembelajaran matematika pada umumnya hanya menggandalkan buku dan kemampuan guru dalam menyampaikan materi, sehingga terjadi beberapa permasalahan di kelas. Untuk mengatasi hal tersebut maka diperlukan suatu media untuk membantu pembelajaran di kelas. Blabak Trarerodi merupakan salah satu media yang dapat digunakan pembelajaran di kelas khusus pada materi geometri transformasi. Blabak Trarerodi terdiri atas materi translasi, refleksi, rotasi dan dilatasi. Metode yang digunakan dalam penelitian ini adalah pengembangan dengan yang dilakukan peneliti adalah analisis, mendesain media, mengembangkan, mengujicobakan dan merefleksi. Akan tetapi pada penelitian ini hanya sampai
\end{abstract}


tahapan pengembangan media. Hasil dari media ini tentunya sudah diperlihatkan kepada ahli media. Ahli yang memberikan validasi adalah dua teman sejawat yang dalam pembelajarannya juga menggunakan media dengan menggunakan angket yang isinya tentang tampilan dan keefektifan media Ketika digunakan. Hasil dari validasi ini menunjukkan media sudah bisa digunakan dengan beberapa revisi dari masukan validator. Selain itu, media ini juga dapat dibuat sendiri oleh siswa karena langkah dan tata cara penggunaan media juga tersedia.

Kata Kunci: Blabak Trarerodi; Geometri Transformasi; Media Pembelajaran Matematika

\begin{abstract}
Development of Trarerodi Blabak Learning Media on Transformation Geometry Materials: Expert Review Stage. Mathematics learning in general only relies on books and the teacher's ability to convey material, so that there are several problems in the classroom. To overcome this, we need a media to help learning in the classroom. Trarerody Blabak is one of the media that can be used for learning in special classes on transformation geometry material. Trarerody Blabak consists of material translation, reflection, rotation and dilation. The method used in this research is development with what researchers do are analysis, media design, development, testing and reflection. However, in this study only up to the stage of media development. The results of this media must have been shown to media experts. The experts who provided validation were two colleagues who in their learning also used the media by using a questionnaire whose contents were about the appearance and effectiveness of the media when used. The results of this validation show that the media can already be used with several revisions from the validator's input. In addition, this media can also be made by students themselves because the steps and procedures for using the media are also available.
\end{abstract}

Keywords: Mathematics Learning Media; Transformation Geometry; Trarerodi Blabak

\title{
Pendahuluan
}

Media dapat diartikan secara sempit sebagai sistem pembelajaran yang mempunyai komponen alat dan komponen bahan. Sedangkan pengertian lebih luas lagi tentang media dapat diartikan sebagai memaksimalkan pemanfaatan sumber belajar yang tersedia dan komponen pembelajaran demi tercapainya tujuan yang telah ditentukan sebelumnya (Miftah, 2013). Sedangkan media pembelajaran merupakan kemudahan proses belajar mengajar melalui suatu alat sebagai perantara penyampaian, sehingga guru dan siswa terkomunikasikan secara efektif. Guru menjadi terbantu dalam kegiatan pembelajaran dan siswa menjadi lebih mudah untuk memahami dan menerima informasi yang disampaikan. Kemampuan yang dibutuhkan oleh guru adalah dapat menyeimbangkan sehingga berjalan dengan selaras antara metode pembelajaran dengan media pembelajaran. Media pembelajaran digunakan dalam kegiatan 
belajar mengajar untuk mencapai tujuan upaya guru dan siswa saling berbagi untuk menganalisis informasi, sehingga informasi tersebut berguna dapat dijadikan dasar pembelajaran yang berlanjut dan menjadikan belajar pengajaran menjadi efisien dan efektif.

Media pembelajaran sangat berperan penting dalam proses belajar mengajar dikarenakan materi matematika merupakan materi yang bersifat abstrak dan tidak dipahami maka diperlukan alat peraga atau media untuk memperjelas materi yang akan disampaikan. Media dapat membantu siswa dalam belajar dengan melihat dengan nyata sesuatu yang abstrak (Surur, Rais, \& Habib 2017). Motivasi belajar siswa akan sebanding dengan tingkat ketertarikan media pembelajaran yang disiapkan oleh guru (Tafonao, 2018), sehingga media yang disiapkan guru harus dipastikan menarika (Surur, 2018). Sebuah proses pembelajaran yang baik akan membentuk intelektual, berfikir kritis (Khoirunnisa \& Malasari, 2021), dan munculnya kreatifitas serta perubahan perilaku atau pribadi seseorang. Hal ini harus dipersiapkan sebelumnya supaya memperoleh hasil sesuai tujuan (Surur, 2020a). Proses pembelajaran dapat diterapkan dan memperoleh hasil yang maksimal apabila komponen-komponen pembelajaran terpenuhi, yaitu meliputi guru, siswa, metode pembelajaran, materi pembelajaran dan media pembelajaran (Auliya, 2018). Memang, keberadaan media tidak selalu dapat diadakan oleh guru dalam pembelajaran, sehingga pembelajaran hanya menggunakan bahan yang tersedia dan ini juga adapat membuat pembelajaran tetap berjalan. Akan tetapi, kemungkinan tingkat keberhasilannya dapat lebih tinggi apabila pembelajaran menggunakan media. Keberhasilan proses belajar mengajar dapat ditunjang dengan penguasaan media oleh guru dan juga menggunakan media pembelajaran yang telah disiapkan (Surur \& Cholifah, 2018).

Pentingnya penggunaan media dalam pembelajaran dengan melihat situasi yang terjadi di lapangan (Anwar \& Anis, 2020). Keterbatasan waktu untuk penyampaian materi pembelajaran. Materi pembelajaran transformasi geometri termasuk materi pembelajaran matematika yang mempunyai banyak sub-bab materi yaitu materi translasi, refleksi, rotasi, dan dilatasi. Sedangkan dalam menyampaikan materi pembelajaran, pendidik memiliki waktu yang terbatas. Pendidik menyampaikan materi dengan lisan dan menulisnya di papan. Hal ini memerlukan waktu yang banyak untuk menyelesaikan materi.

Selain itu, suasana dalam kelas yang sulit diperkirakan (gaduh atau kurang fokus) terkadang sering terjadi. Sementara kondisi kelas yang kondusif adalah kondisi yang ideal, sehingga proses pembelajaran akan berjalan sesuai dengan tujuan pembelajaran. Tapi yang terjadi di lapangan sebaliknya, kondisi kelas tidak 
kondusif, mengakibatkan proses pembelajaran tidak sesuai target, karena materi yang tersampaikan hanya sebgaian. Selain itu guru tidak menggunakan media selain buku yang tersedia, Sulitnya merancang media pembelajaran agar semua sub-bab materi pembelajaran tercantum didalamnya. Beberapa siswa tidak fokus dengan materi yang diberikan dan kondisi kelas yang kurang kondusif. Hal ini disebabkan karena kondisi kelas ramai, siswa mengantuk, bosan teralami, capek, dan situasi di luar kelas.

Keberhasilan pembelajaran didukung oleh banyak pihak yang terkait. Tidak hanya ditentukan oleh guru saja, tetapi juga faktor yang lainnya. Faktor yang juga menentukan keberhasilan pembelajaran adalah keaktifan siswa dalam mengikuti pembelajaran, fasilitas belajar yang tersedia, kenyamanan kelas belajar dan ruangan kelas yang aman (Fakhrurrazi, 2018). Selain itu, karena belajar bermakna yang dialami oleh siswa dengan adanya pengaitan pembelajaran matematika dengan aktivitas kehidupan (Izah \& Malasari, 2021; Zakiyah \& Malasari, 2021). Ketika pembelajaran terjadi masalah di atas yang ditemuai peneliti ketika pembelajaran berlangsung. Oleh karena itu, penggunaan media Blabak Trarerodi ini untuk menarik perhatian siswa dan menjadikan siswa lebih fokus untuk mempelajari serta menahami materi pembelajaran yaitu transformasi geometri.

Berdasarkan permasalahan-permasalahan tersebut, terdapat solusi untuk penyelesaian masalah tersebut. Langkah yang dapat ditempuh yaitu, sebelum pembelajaran dimulai, pembelajaran dengan media blabak trarerodi harus benarbenar disiapkan terlebih dahulu mulai dari membuat blabak atau papan trarerodi dengan menancapkan paku-paku kecil, dan lain sebagainya karena semua persiapan pasti membutuhkan waktu yang tidak sedikit. Selain itu, guru sebagai fasilitator dan motivator harus mampu membangkitkan kesadaran siswa akan pentingnya mempelajari sebuah materi. Jika guru menjelaskan materi dan siswa benar-benar memperhatikan maka waktu tidak akan terbuang sia-sia.

Guru harus memiliki banyak cara agar siswa tetap fokus memperhatikan saat pembelajaran dengan memberikan pertanyaan kepada siswa dengan cara menunjuk siswa (Surur, 2018) (terutama yang terlihat kurang fokus) misalnya siswa disuruh menjelaskan sedikit materi yang sudah dijelaskan. Atau usaha lain yang dapat digunakan adalah dengan menerapkan metode pembelajaran tertentu (Surur, 2018). Kemudian atur irama pembelajaran menjadi santai kemudian serius lagi, dan begitu seterusnya. Bisa juga menyuruh siswa maju kedepan untuk mempraktekkan materi transformasi agar siswa lebih paham dan mengerti. Kegiatan yang dapat menghilangkan kebosanan dalam mengikuti pelajaran dengan mengubah kegiatan belajar menjadi menarik dan terkendalinya kegiatan di kelas. 
Guru memberikan pengalaman belajar kepada siswa akan antusias dan aktif mengikuti pembelajaran (Razaq, 2009).

Blabak Trarerodi dapat membuat grafik cartesius pada sebelah kiri dan tabel matriks yang berada di sebelah kanan Blabak Trarerodi. Dengan demikian semua sub-bab materi transformasi geometri dapat disampaikan dalam media pembelajaran. Dengan menggunakan media pembelajaran Trarerodi, pembelajaran di dalam kelas akan menyenangkan dan inovatif. Oleh karena itu, siswa dapat memberikan hasil belajar yang baik serta guru lebih mudah mencapai tujuan pembelajaran.

Beberapa penelitian sebelumnya juga menggunakan papan sebagai media pembelajaran. Hasil dari penelitian menunjukkan bahwa kelayakan media pembelajaran papan baca pintar berbasis literasi sains (Oktaviani, Andari, \& Bua, 2020). Selain itu hasil dari penelitian lain menunjukkan bahwa menurut siswa media pembelajaran papan flanel berputar sangat layak digunakan dalam proses pembelajaran dari data yang dihasilkan melalui angket respon siswa (Rahayu \& Paksi, 2018). Selain itu hasil penelitian lain juga menunjukkan bahwa penggunaan media papan raba dapat meningkatkan kemampuan mengenal lambang bilangan pada anak kelompok A (Fitria, Uce, \& Hayati, 2019). Penelitian juga menghasilkan disimpulkan bahwa ada pengaruh penggunaan media papan flanel terhadap minat belajar siswa kelas VII pada mata pelajaran matematika (Sakti \& Farhan, 2020). Dari beberapa penelitian tersebut menunjukkan keberadaan media sangat membantu proses pembelajaran, dan mengenai bentuk dari media tersebut sudah menjadi media yang mudah digunakan oleh siswa.

\section{Landasan Teori}

Geometri merupakan salah satu cabang ilmu dalam matematika dan memiliki keterkaitan erat dengan aktivitas kehidupan siswa (Malasari, Herman, \& Jupri, 2019; Malasari, Herman, \& Jupri, 2020). Salah satu sub materi yang terdapat dalam geometri adalah trasformasi geometri. Transformasi geometri merupakan perubahan yang terjadi seperti perpindahan posisi, ukuran yang berubah dan kemungkinan perubahan bentuk pada suatu bidang geometri. Sedangkan transformasi isometri apabila hasil transformasi kongruen dengan bangunan yang ditranformasikan. Terdapat dua jenis dari transformasi isometri yaitu transformasi isometri berhadapan dan transformasi isometri langsung. Translasi dan rotasi termasuk dalam golongan transformasi isometri langsung, sedangkan transformasi isometri berhadapan termasuk dilatasi dan refleksi (Jamil, 2019). 
Bentuk dapat berpindah ke sembarang titik dan posisi pada transformasi, dapat berpindah ke atas, bawah, kiri, kanan atau bahkan dapat berpindah ke segala arah. Perputaran kesegala arah dapat dilakukan dengan memutar dengan besaran sudut tertentu. Perputaran dapat berbentuk garis lurus atau juga membentuk lingkaran. Beberapa cara yang dapat dilakukan dalam transformasi geometrik, seperti translasi (pergeseran), refleksi (pencerminan), rotasi (perputaran) dan dilatasi (penskalaan).

Transformasi dengan memindahkan titik tertentu di sepanjang garis lurus dengan arah dan jarak tertentu disebut translasi (Jamil, 2019). Sedangkan pergeseran yang hanya mengubah posisi pada titik yang tidak mengubah ukuran dan bentuknya dinamakan dengan translasi. Translasi merupakan transformasi yang dihasilkan kekongruenan dengan bentuk yang ditransformasikan termasuk transformasi isometri langsung.

Rotasi adalah transformasi yang diperoleh dari hasil memutar suatu titik pada bidang ke titik lainnya pada pusat titik tertentu. Tranformasi rotasi dilakukan dengan melakukan perpindahan titik-titik pada objek tertentu menuju pada posisi yang baru dengan cara memutar titik-titik tersebut dengan sumbu dan sudut putar yang ditentukan (Dinak, 2016). Perlakuan rotasi akan membuat ukuran objek tetap, sehingga dapat dimasukkan dalam transformasi isometri langsung.

Refleksi adalah memindahkan bangun geometri atau benda dengan jarak yang memiliki nilai yang sama antara titik perpindahan dengan cermin dan titik awal dengan cermin (Roebyanto, 2014). Objek yang direfleksikan akan menghasilkan bayangan benda yang disebabkan oleh sebuah cermin. Hasil refleksi tergantung pada sumbu yang menjadi cerminnya dalam bidang kartesius. Semua titik yang mengalami refleksi akan dipindahkan dengan menggunakan sifat pencerminan pada cermin datar. Transformasi yang dihasilkan kongruen dengan bangunan yang ditransformasikan. Refleksi termasuk ke dalam transformasi isometri berhadapan.

Dilatasi dapat ditentukan oleh titik pusat dan faktor (faktor skala) dilatasi. Dilatasi merupakan suatu transformasi yang mengubah ukuran suatu bangun (pembesaran atau perkalian atau memperkecil atau memperbesar) dengan bentuk bangun yang tidak berubah, tetap seperti sebelumnya (Irmawati, 2020).

\section{Metode}

Metode penelitian yang digunakan adalah metode penelitian dan pengembangan. Metode ini digunakan oleh peneliti untuk menghasilkan suatu 
produk (Surur, 2020b) berupa media pembelajaran yang dinamakan Trarerodi yang selanjutnya akan diuji kefektifan media tersebut. Metode penelitian pengembangan didefinisikan sebagai suatu metode penelitian yang digunakan untuk menghasilkan suatu produk tertentu dan selanjutnya mengujinya (Sugiyono, 2014). Pengembangan merupakan proses perjalanan dari spesifikasi rancangan yang kemudian diterjemahkan menjadi suatu bentuk kongkrit (Richey \& Klein, 2007). Rancangan ini berkaitan dengan desain belajar yang sistematik, pengembangan media atau model pembelajaran dan evaluasi produk. Tujuan dari pengembangan ini adalah untuk meningkatkan media atau metode yang sudah ada.

Model pengembangan yang digunakan adalah model ADDIE. Model ADDIE digunakan sebagai pendekatan system yang digunakan dalam pengembangan media. Hal khusus yang ada pada model ADDIE adalah pada tahap perencanaannya yang terbagi menjadi beberapa Langkah. Langkah yang ditunjukkan adalah Langkah logis yang mudah diterapkan. Selain itu juga terdapat tatacara penggunaanya sehingga sesuai dengan tujuan penggunaan media(Januszewski \& Molenda, 2008). Model Intruksional ADDIE Merupakan proses instruksional yang terdiri dari lima fase, yaitu analisis, desain, pengembangan, implementasi dan evaluasi yang dinamis (Cahyadi, 2019). Pada media ini sudah sampai tahapan pengembangan (development), yaitu media sudah siap digunakan dalam pembelajaran.

Pada tahap analisis peneliti mengumpulkan beberapa keterangan dari pihak yang terkait denga pembelajaran, yaitu guru dan siswa untuk memperoleh permasalah yang terjadi di lapangan. Permasalahan tersebut kemudian dirumuskan beberapa kemungkinan yang dapat ditempuh untuk menyelesaikan masalah tersebut, salah satunya dengan mengadakan suatu media pembelajaran.

Setelah proses analisis, peneliti mendesain media yang akan digunakan. Desain dibuat dengan memperhatikan bahan dan alat yang mudah ditemukan dan mudah diperoleh. Setelah alat dan bahan diperoleh, penelit membuat desain media hingga ketahap produksi media. Setelah media selesai dibuat, media siap untuk diberikan penilaian kepada ahli media.

Validator yang dipilih adalah teman sejawat yang dalam mengajar juga menggunakan media dalam beberapa materi matematika. Bagian yang divalidasi mencakup caara membuat media, tampilan media, bentuk media, pemilihan warna media, keterbacaan tulisan yang berkaitan dengan media, daya tahan media, penggunaan ulang media, kemudahan penggunaan media dan cara penyimpanan 
media. Hasil dari validasi ini akan digunakan untuk merevisi media sehingga dapat digunakan pada tahap berikutnya.

\section{Hasil dan Pembahasan}

\section{Karakteristik Media Blabak Trarerodi}

Karakteristik media terhadap media Blabak Trarerodi yang kami buat yaitu:

1. Karakteristik eksplanatif. Media pembelajaran mempunyai karakteristik eksplanatif, karena materi dapat diperjelas dengan menggunakan media pembelajaran yang disampaikan secara lisan oleh guru.

2. Karakteristik distributif. Media pembelajaran ini dapat digunakan untuk menyampaikan materi transformasi kepada siswa, sehingga media ini membantu guru untuk membelajarkan materi transformasi kepada siswa. Selain itu, media juga dapat dijangkau secara serentak oleh siswa karena Bersama-sama dalam menggunakan media tersebut.

3. Karakteristik aksesibilitas. Media pembelajaran ini mudah dijangkau karena bahan dan alat yang digunakan mudah ditemuai di lingkungan sekitar guru atau siswa. Selain itu, tahapan dalam membuatnya juga runtuk dan mudah dipahami, sehingga mudah untuk diterapkan. Dengan kemudahan dalam menjangkau media, bisa diupayakan siswa membuat secara mandiri/kelompok dengan arahan dari guru.

4. Karakteristik manipulatif distributif. Karena penggadaan media ini cukup mudah maka ukurannya dapat disesuaikan dengan selera pengguna, dengan tetap menjaga esensi materi yang terdapat dalam media.

\section{Peran Media Blabak Trarerodi}

1. Memberikan kesamaan pengalaman. Dengan adanya media ini, guru dapat memberikan sejumlah pertanyaan- pertanyaan kepada siswa terkait dengan materi transformasi geometri menggunakan media Blabak Trarerodi. Sehingga, akan menimbulkan pengalaman yang sama diantara peserta didik.

2. Memperjelas penyajian pesan dan informasi. Dalam hal ini media berperan untuk memudahkan siswa dalam memahami konsep transformasi geometri serta menghindari kesalahfahaman terhadap konsep transformasi geometri. Dengan menggunakan media, siswa tidak hanya menghafal rumus (teori) 
saja. tetapi dapat melihat penerapannya langsung di media. Diharapkan pula siswa tidak akan mengalami kesalahfahaman antara satu konsep dengan konsep lainnya didalam materi transformasi geometri. Materi transformasi geometri menjadi mudah karena sudah belajar mulai dari konsep dasarnya dengan menggunakan media. Selain itu, juga dapat meningkatkan daya ingat terhadap materi transformasi geometri.

3. Meningkatkan dan mengarahkan perhatian media yang unik. Dalam hal ini media berperan untuk membangkitkan minat siswa mengenai transformasi geometri dan melatih proses berpikir secara kontinu. Sebab, kebanyakan siswa akan mudah bosan jika materi disajikan secara lisan seperti pada umumnya, dengan adanya media ini agar siswa lebih meningkatkan minat dalam mempelajari materi transformasi geometri. Apabila minat meningkat, semangat juga akan meningkat sehingga mempengaruhi pola berpikir secara kontinu.

\section{Hubungan antara Media dengan Materi Matematika.}

Sebuah proses pembelajaran yang terstruktur berdasarkan praktik atau pengalaman tertentu akan melatih berfikir kritis, meningkatkan intelektual, dan munculnya serta meningkatkan kreatifitas, juga perubahan perilaku atau pribadi seseorang. Proses pembelajaran adalah proses berbagi dan mengolah informasi yang menjadi upaya Bersama antara guru dan siswa supaya dapat mengambil manfaat. Selain itu juga sebagai landasan belajar yang berkelanjutan. Dengan demikian proses belajar mengajar menjadi efektif dan efisien. Proses pembelajaran tidak akan berjalan lancar apabila tidak ada komponen-komponen pembelajaran. Komponen-komponen pembelajaran merupakan suatu sistem yang utuh dan saling mendukung satu sama lain (Jufri, 2016). Komponen penting yang pertama adalah guru, sehingga didalam proses belajar mengajar guru dituntut menciptakan suasana belajar yang kondusif sehingga memungkinkan dan mendorong siswa untuk mengembangkan segala kreativitasnya dengan bantuan guru. Komponen penting yang lainnya yaitu siswa, materi pembelajaran, metode pembelajaran, media pembelajaran, dan yang terakhir adalah evaluasi pembelajaran.

Media pembelajaran sangat berperan penting dalam proses belajar mengajar dikarenakan materi matematika merupakan materi yang bersifat abstrak dan tidak mudah dipahami maka diperlukan alat peraga atau media untuk memperjelas materi yang akan disampaikan, dalam hal ini khususnya materi transformasi geometri. Penggunaan media bukan berarti menggantikan kedudukan guru ataupun sumber belajar, namun dengan adanya media 
pembelajaran menjadikan sebuah alat yang membantu efisiensi dan efektivitas proses belajar mengajar. Oleh karena itu, dengan bantuan media atau alat peraga dapat mempertinggi kegiatan belajar peserta didik dan dengan bantuan media akan menghasilkan proses dan hasil belajar yang lebih baik daripada tanpa bantuan media atau alat peraga.

Media Blabak Trarerodi dalam pembelajaran matematika memiliki arti sebuah papan yang didesign sedemikian rupa sehingga membentuk sebuah susunan proses penyelesaian terkait materi transformasi geometri. Tujuan pembuatan media unik ini tentunya untuk memberikan gambaran dan penjelasan secara singkat, runtut, dan sistematis terkait proses penyelesaian materi yang terkandung didalam transformasi geometri yang meliputi sub bab translasi (pergeseran), refleksi (pencerminan), rotasi (perputaran), serta dilatasi (penskalaan). Disamping itu, media Blabak Trarerodi bertujuan untuk menarik minat siswa untuk belajar materi transformasi geometri secara menyenangkan dan menanamkan anggapan bahwa materi transformasi geometri adalah materi yang mudah dalam pembelajaran matematika. Dalam pembelajaran matematika, penggunaan media Blabak Trarerodi diharapkan dapat membantu mengatasi kesulitan dalam memahami materi terkait translasi, refkesi, rotasi, dan dilatasi ketika proses kegiatan pembelajaran berlangsung. Dengan adanya media Blabak Trarerodi ini, siswa akan mendapatkan pengalaman visual secara jelas terkait proses penyelesaian materi transformasi geometri.

Media Blabak Trarerodi memiliki banyak keunggulan diantaranya adalah cara pembuatannya yang mudah dengan menancapkan paku-paku kecil yang dikasih benang, sangat praktis dan memperjelas sistematika proses pengerjaan transformasi geometri, media ini mengemas pembelajaran dengan praktis, kreatif, dan inovatif, media dapat digunakan secara berulang-ulang pada tahun ajaran berikutnya, dapat digunakan di dalam atau di luar ruangan karena papan Trarerodi ini tidak menggunakan arus listrik, serta bahan yang digunakan untuk pembuatan media pembelajaran ini relatif murah.

Berdasarkan asumsi diatas, dapat disimpulkan bahwa penggunaan media Blabak Trarerodi dalam pembelajaran matematika khususnya pada pokok bahasan mengenai transformasi geometri meliputi translasi, refleksi, rotasi, dan dilatasi sangat erat kaitannya dengan hasil proses pembelajaran. Hal ini dapat terlihat bahwa hubungan antara tenaga pendidik dan peserta didik dapat berlangsung secara interaktif dan menyenangkan, sebab pemakaian media Blabak Trarerodi memberikan banyak manfaat serta dampak positif dalam proses pembelajaran matematika. 
Media berbentuk papan juga sudah dilakukan oleh peneliti terdahulu. Hasil yang ditunjukkan juga positif. Media papan tempel yang telah dikembangkan dinilai memiliki daya tarik yang baik bagi siswa dalam pembelajaran (Putra, Hunaifi, \& Saidah, 2018). Ketertarikan siswa terhadap media menjadi salah satu poin penting dalam penggunaan media. Setelah siswa tertarik, guru memberikan pengarahan tentang penggunaan media yang dihubungkan dengan materi. Media pembelajaran papan berpaku dapat meningkatkan pemahaman konsep pengukuran luas bangun datar pada mata pelajaran Matematika (Masitoh \& Habudin, 2018). Papan ini memang tidak menggunakan paku, akan tetapi menggunakan yang sejenis. Penggunaan ini disesuaikan dengan bentuk media yang membutuhkan penancapan sesuatu untuk memperjelas materi. Dari itu, dapat disimpulkan penggunaan papan dan paku menjadi bagian dari media ini dan dapat menjadi bagian yang menarik dan menyesuaikan dengan media.

\section{Hasil Validasi Media}

Bagian yang divalidasi mencakup cara membuat media, tampilan media, bentuk media, pemilihan warna media, keterbacaan tulisan yang berkaitan dengan media, daya tahan media, penggunaan ulang media, kemudahan penggunaan media dan cara penyimpanan media. Hasil dari validasi ini akan digunakan untuk merevisi media sehingga dapat digunakan pada tahap berikutnya.

Secara umum, media sudah dapat digunakan dalam pembelajaran. Secara detailnya, hasil dari validasi menunjukkan bahwa media mudah dibuat karena sudah tersedia tatacara pembuatan media. Dari tampilan media juga sudah cukup menarik dengan menggunakan kombinasi beberapa warna. Tentang bentuk media, beberapa ada masukkan akan tetapi sudah dapat digunakan. Daya tahan yang ditunjukkan media juga sudah cukup kuat karena terbuat dari papan, dan ini berhubungan dengan cara penyimpanan. Penggunaan media yang dapat digunakan berulang juga baik, karena media nantinya bisa digunakan lagi tentang materi yang terkait.

Walaupun hasil sudah baik, namun ada beberapa bagian yang perlu diperbaiki. Hal ini dihubungan dengan per materi yang disampaikan. Translasi. Bagian kotak-kotak terlalu besar. Walupun kelihatan jelas, tapi angkanya sangat terbatas. Perkecil kotak-kotak dengan tetap usahakan terlihat. Penggunaan jarum diganti dengan yang paling mudah dan terlihat atasnya, sehingga terlihat seperti titik. Penggunaan karet dapat merusak bentuk karena terkena tekanan, diganti dengan penggunaan benang yang dililitkan, sehingga bisa untuk ukuran yang besar. 
Refleksi. Memberikan sumbu x dan y yang lebih jelas. Bisa dibuat dengan gambar yang lebih tebal dari garis lain sebagai pembeda. Rotasi. Menggunakan alat bantu rotasi yang bisa digunakan. Memilih warna yang cerah sehingga Ketika diberikan angka atau garis akan terlihat dan mudah untuk diberikan angka atau huruf atau garis. Dilatasi. Memperbanyak pilihan angka, sehhingga penggunaan media akan bisa lebih luas pada angka-angka yang cukup besar.

\section{Langkah/ Tahapan Pembuatan Media Blabak Trarerodi}

Berikut ini adalah langkah atau tahapan dalam pembuatan media pembelajaran matematika berjudul Blabak Trarerodi.

1. Siapkan alat-alat dan bahan-bahan yang diperlukan untuk membuat media Blabak Trarerodi.

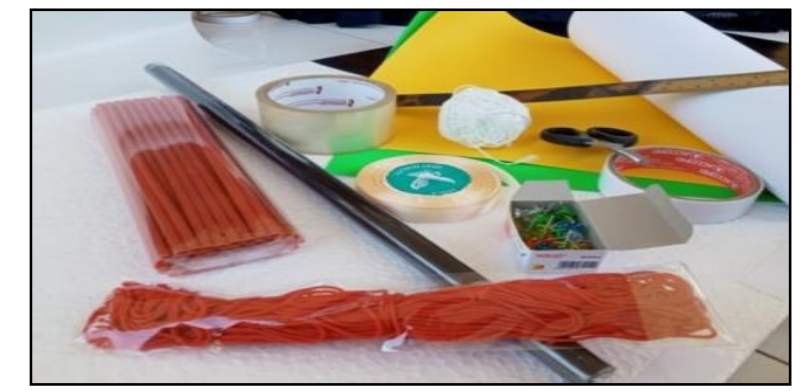

Gambar 1. Bahan untuk membuat media Trarerodi

2. Langkah pertama dalam pembuatan media pembelajaran matematika Blabak Trarerodi adalah menyiapkan alat-alat dan bahan-bahan yang diperlukan. Dalam membuat media pembelajaran ini alat-alat dan bahanbahan yang digunakan, cukup mudah diperoleh dan harganya pun cukup terjangkau. Bahan-bahan yang digunakan adalah sebagai berikut: Sterofom, Double tipe, Isolatip, Kertas kado warna hitam, Kertas pelangi warna kuning dan hijau, Pita warna orange pudar, Benang songket warna putih, Benang rajut warna merah, Sedotan, Paku mading, Alat-alat yang digunakan adalah sebagai berikut : Gunting, Penggaris, Spidol.

3. Bagi sterofom menjadi dua bagian sama panjang. Sterofom yang digunakan mempunyai ketebalan $2 \mathrm{~cm}$. Karena ketebalan tersebut merupakan ketebalan yang paling cocok untuk membuat media blabak Trarerodi, tidak terlalu tipis sehingga tidak mudah patah. Dan sterofom tersebut berukaran $100 \mathrm{~cm} \times 50 \mathrm{~cm}$, jadi langkah selanjutnya adalah membagi sterofom menjadi dua bagian sama panjang. Bagian sebelah kiri akan digunakan untuk 
membuat grafik cartesius dan bagian sebelah kanan akan digunakan untuk membuat matriks-matriks.

4. Lapisi bagian atas sterofom menggunakan kertas kado atau kertas lapis bewarna hitam. Setelah membagi sterofom menjadi dua bagian yang sama panjang, langkah selanjutnya adalah lapisi bagian atas sterofom dengan menggunakan kertas kado atau kertas lapis bewarna hitam. Penggunaan kertas kado bewarna hitam ini bertujuan agar media pembelajaran tidak mudah kotor. Selain itu grafik dan matriks akan terlihat semakin jelas apabila background blabaknya bewarna gelap terutama warna hitam.

5. Buatlah sumbu x dan y menggunakan pita pada sterofom bagian kiri. Langkah selanjutnya adalah potong pita dengan panjang yang sesuai dengan panjang dan lebar sterofom pada bagian kiri. Kemudian tempelkan pita tersebut pada tepat pertengahan panjang dan lebar sterofom bagian kiri. Buatlah titik koordinat sumbu $\mathrm{x}$ dengan bantuan paku mading dan penggaris.

6. Langkah berikutnya adalah membuat titik koordinat sumbu $\mathrm{x}$ pada cartesius. Yang pertama dilakukan dalam langkah ini adalah ukur lebar sterofom bagian kiri yang akan digunakan sebagai sumbu x pada grafik cartesius dan tandai setiap satu sentimeternya dengan menggunakan paku mading.

7. Hubungkan titik-titik koordinat pada cartesius menggunakan benang songket bewarna putih. Selanjutnya potong benang songket bewarna putih sebanyak panjang sumbu x grafik cartesius dengan panjang yang lebih panjang dari panjang sumbu x agar dapat direkatkan pada bagian belakang sterofom. Penggunaan benang songket bewarna putih ini adalah agar titik koordinat sumbu x terlihat lebih jelas karena memiliki warna yang kontras dengan background blabaknya. Berikutnya adalah rekatkan setiap benang songket yang telah dipotong pada setiap satu sentimeter sumbu x grafik cartesius.

8. Lakukan langkah yang sama untuk sumbu y hingga terbentuk bidang cartesius secara lengkap. Setelah membuat titik koordinat sumbu x langkah selanjutnya adalah membuat sumbu y seperti langkah membuat titik koordinat sumbu x yang sudah dijelaskan diatas dengan menempel benang songket berwarna putih secara horizontal. Setiap titik koordinat mewakili ukuran $1 \mathrm{~cm}$. 
9. Beri pita dobel pada sumbu $\mathrm{x}$ dan sumbu y agar sumbu koordinat cartesius tampak lebih jelas dan cantik. Setelah selesai membuat sumbu x dan sumbu y langkah selanjutnya adalah memberi pita dobel pada sumbu koordinat tersebut. Caranya adalah menempel pita tepat di atas pita yang sudah dibuat seperti pada langkah ke-4 secara vertikal dan horizontal. Tujuan dari memberi pita dobel adalah agar sumbu cartesius pada grafik terlihat jelas dan cantik karena pita pada sumbu koordinat tertimbun dengan benang songket pada sumbu $\mathrm{x}$ dan sumbu y.Menempelkan sedotan pada bagian lain sterofom.

10. Setelah selesai dengan bagian blabak Trarerodi bagian kiri, kemudian kita mengisi bagian lain dari blabak Trarerodi. Potong sedotan dengan ukuran \pm $3 \mathrm{~cm}$. Susun dan tempelkan sedotan pada sterofom bagian kanan yang akan digunakan untuk menyelesaikan permasalahan transformasi geometri dengan matriks.Setelah sedotan dipotong menjadi kecil-kecil, langkah selanjutnya adalah menyusun dan menempelkan sedotan menjadi seperti huruf $U$ atau berbentuk bingkai yang akan digunakan sebagai tempat meletakkan rumus-rumus yang sesuai dengan cara penyelesaian transformasi geometri dengan matriks.

11. Potong kertas pelangi warna kuning dan hijau menjadi potongan-potongan persegi. Setelah tempat untuk rumus-rumus selesai disusun, langkah selanjutnya adalah memotong kertas pelangi warna kuning dan hijau untuk menuliskan rumus-rumus tersebut. Kertas warna kuning digunakan untuk rumus-rumus translasi dan rotasi, sedangkan kertas warna hijau digunakan untuk rumus-rumus refleksi dan dilatasi.

12. Masukkan potongan kertas tersebut kedalam bingkai sedotan yang telah dibuat. Setelah kertas pelangi warna kuning dan hijau dipotong menjadi potongan-potongan persegi, langkah selanjutnya adalah masukkan potongan-potongan persegi tersebut kedalam bingkai sedotan yang telah dibuat. Letakkan potongan-potongan persegi sesuai warnanya. Tulislah rumus-rumus penyelesaian transformasi geometri menggunakan matriks dengan spidol. Langkah berikutnya setelah potongan-potongan persegi diletakkan kedalam bingkai sedotan adalah tulislah rumus-rumus penyelesaian transformasi geometri menggunakan matriks dengan spidol warna gelap agar tulisan rumus-rumus terlihat lebih jelas.

13. Dan langkah terakhir potong kertas warna putih untuk memberi judul pada setiap rumus-rumus pada penyelesaian transformasi geometri menggunakan matriks. Dan langkah selanjutnya merupakan langkah yang 
terakhir yaitu potong kertas warna kuning untuk memberi judul pada setiap rumus-rumus pada penyelesaian transformasi geometri menggunakan matriks. Namun yang digunakan untuk menuliskan judul adalah belakangnya kertas warna kuning yang bewarna putih. Hal ini bertujuan untuk membedakan antara judul dan rumus-rumus.

14. Media pembelajaran Blabak Trarerodi siap untuk digunakan dalam materi pembelajaran Transformasi Geometri meliputi translasi, refleksi, rotasi, dan dilatasi.

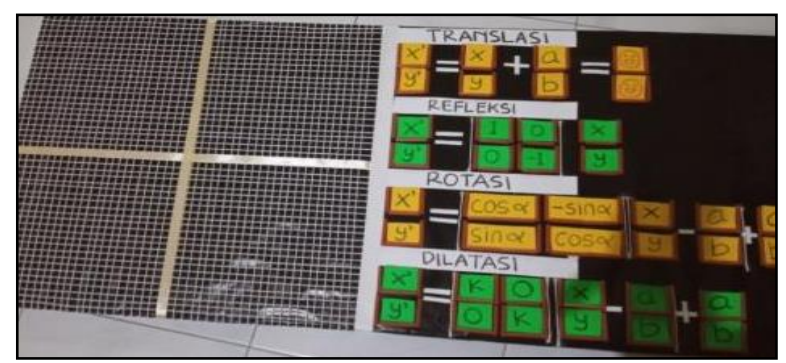

Gambar 2. Bentuk akhir Media Trarerodi

\section{Tata Cara Penggunaan Media Blabak Trarerodi}

Berikut ini adalah tata cara penggunaan media embelajaran matematika "Blabak Trarerodi".

Sebelum masuk dalam pembahasan sub-bab transformasi geometri yang lebi dalam. Langkah paling utama yang harus dikerjakan adalah menyiapkan peralatan-peralatan lain yang mendukung penyampaian materi menggunakan Blabak Trarerodi. Misalnya menyimpkan benang, kertas bertuliskan angka-angka untuk diterapkan pada media tabel matriksnya, dan paku mading yang berwarnawarni.

Langkah keduanya yaitu menyiapkan butir soal yang akan dijelaskan menggunakan media Blabak Trarerodi. Langkah kedua sangat penting dilakukan karena, dengan adanya butir soal inilah yang akan dicari penyelesaannya dengan menggunakan media. Selanjutnya adalah memasang judul dan butir soal pada Blabak Trarerodi dengan bantuan paku mading pada keempat sisinya. Hal ini bertujuan agar saat menyelesaikan soal dengan media, kita tidak mudah lupa dengan soal yang ditanyakan karena sudah tertempel dengan jelas.

Selanjutnya yaitu cara penggunaan media pembelajaran Blabak Trarerodi pada materi transformasi geometri. Pertama, cara penggunaan media pembelajaran Blabak Trarerodi pada sub-bab translasi. Tidak lupa untuk selalu menempelkan judul dan butir soal terlebih dahulu dimedia. 


\section{Translasi}

Setelah menyiapkan butir soal yang akan dikerjakan dan memasang judul pada media Blabak Trarerodi, langkah selanjutnya adalah menyiapkan paku mading yang jumlahnya sebanyak titik dalam butir soal. Kemudian tancapkan paku-paku mading tersebut pada media pembelajaran Black Trarerodi pada bagian kanan yaitu grafik kartesius. Paku-paku mading tersebut ditancapkan dengan posisi yang sesuai dengan titik pada butir soal.

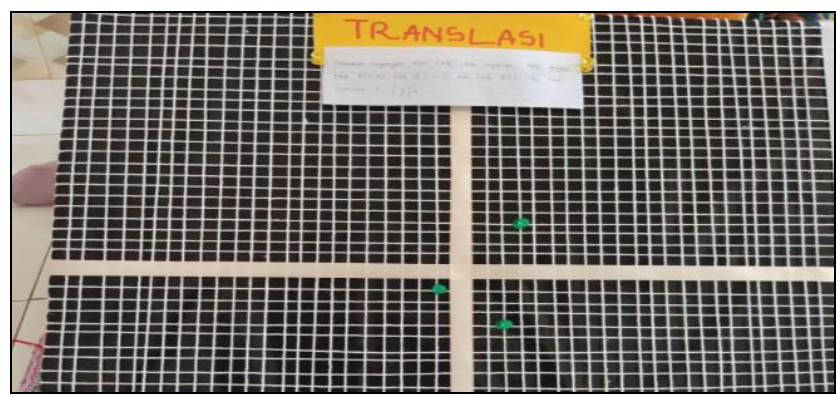

Gambar 3. Media untuk Menjelaskan Materi Translasi

Langkah selanjutnya adalah menyiapkan benang rajut warna merah dan ikatkan benang rajut tersebut pada paku-paku mading yang telah ditancapkan pada grafik kartesius sehingga membentuk bidang datar yang sesuai dengan butir soal.

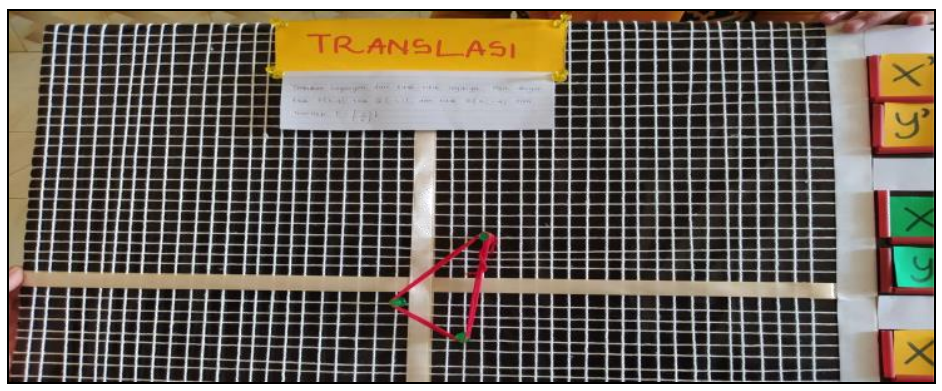

Gambar 4. Materi Translasi dengan Media Trarerodi

Dengan menerapkan materi translasi transformasi geometri, maka telah diketahui jawaban dari setiap permasalahan dalam butir soal yang telah disiapkan. Setelah mengetahui jawaban dari setiap permasalahan dalam butir soal, langkah selanjutnya adalah siapkan paku mading yang warnanya berbeda dengan pakupaku yang telah digunakan sebelumnya. Kemudian tancapkan paku-paku mading tersebut pada grafik kartesius sesuai dengan posisi yang sesuai dengan jawaban yang telah diketahui. 
Selanjutnya siapkan benang rajut warna merah lagi dan ikatkan pada setiap paku-paku madingnya hingga membentuk sebuah bidang datar. Dengan terselesaikannya butir soal tersebut, maka semakin terlihatlah konsep dari materi translasi transformasi geometri pada media pembelajaran Blabak Trarerodi.

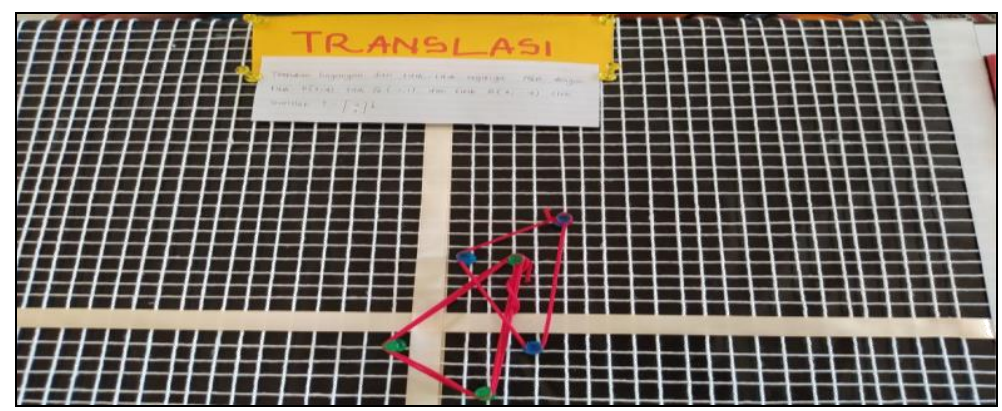

Gambar 5. Penggunaan Media pada Materi Translasi

Selain cara penggunaan media pembelajaran Blabak Trarerodi pada grafik bagian kiri blabak, ada cara lain yang lebih sederhana karena sudah terdapat matriks atau rumus dari materi translasi. Langkah pertama yaitu menyiapkan butir soal yang akan dikerjakan. Selanjutnya tentukan nilai titik $(x, y)$ dalam butir soal. Setelah mengetahui nilai dari titik $(x, y)$, emudian tentukan nilai $a$ yang merupakan nilai pergeseran dari titik $x$ dan nilai $y$ yang merupakan nilai pergeseran dari titik $y$.

Setelah mengetahui nilai titik $(x, y)$ serta nilai $a$ dan $b$, selanjutnya siapkan kertas ber bentuk persegi sebanyak titik $(x, y)$ dalam contoh butir soal serta nilai $a$ dan $b$. Kemudian tuliskan nilai-nilai yang telah diketahui dari butir soal pada kertas-kertas persegi tersebut. Selanjutnya masukkan kertas-kertas yang sudah berisikan nilai-nilai tersebut kedalam bingkai sedotan. Pastikan kertas-kertas persegi yang sudah berisikan nilai-nilai tersebut masuk sesuai simbol yang sudah ada dalam bingkai-bingkai sedotan. Dan langkah terakhir adalah hitung nilai-nilai yang sudah masuk dalam bingkai kotak sesuai dengan rumus yang tertera pada media pembelajaran blabak trarerodi pada bagian kiri.

\section{Refleksi}

Kedua, cara penggunaan media pembelajaran Blabak Trarerodi pada subbab refleksi. Tidak lupa untuk selalu mengganti judul dan butir soal yang akan dikerjakan menggunakan media Blabak Trarerodi. Sebelum menerapkan soal kedalam media, maka siapkan terlebih dahulu paku Mading untuk menandai titik yang diketahui didalam soal pada bidang cartesius. Setelah itu, baca kembali soal tranformasi geometri terkait dengan refleksi. Apakah titik yang diketahui tersebut 
direfleksikan terhadap sumbu-x atau sumbu-y. Pada kali ini, titik yang diketahui direfleksikan terhadap sumbu-x negatif. Oleh karena itu, gunakan paku Mading berwarna untuk menandai titik awal yang diketahui yaitu $(5,-3)$.

Setelah itu, diibaratkan sumbu $x$ adalah cermin, maka ada didapatkan titik baru yaitu titik $(-5,3)$. Segera tandai titik baru tersebut dengan paku Mading yang berlainan warna dengan titik yang diketahui disoal. Hal ini bertujuan untuk sebagai pembeda. Dengan demikian, dapat kita ketahui bahwa hasil refleksi titik $(5,-3)$. terhadap sumbu-x negatif adalah $(-5,3)$.

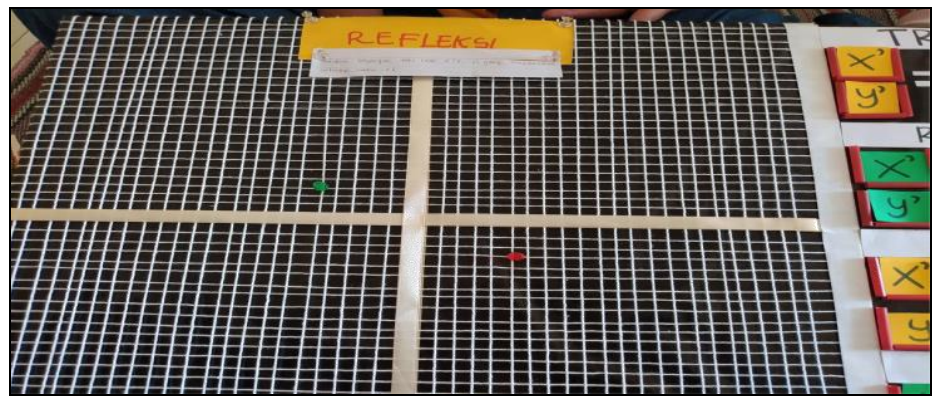

Gambar 6. Media Trarerodi untuk Materi Refleksi

Selain menggunakan cara grafik, dapat dilakukan juga dengan menggunakan media tabel yang berada disebelah kanan grafik. Hal pertama yang harus dilakukan adalah lihat terlebih dahulu matriks pencerminan yang diinginkan. Dalam hal ini matriks pencerminannya terhadap sumbu-x negatif, sehingga tinggal menukarkan saja pada kolom angka 1 dengan kolom angka -1 Kemudian, isikan titik 5 dan titik -3 kedalam kolom betukiskan huruf $a$ dan huruf $b$. Dimana 5 sebagai huruf $a$ dan -3 sebagai huruf $b$. Selanjutnya kita operasikan bentuk matriks dengan titik $a$ dan titik $b$. Dengan demikian akan diperoleh hasil pencerminan terhadap sumbu-x negatif yaitu titik baru $(-5,3)$. Hasil ini membuktikan bahwa pencerminan titik $(5,-3)$ terhadap sumbu-x menunjukkan hasil yang sama jika menggunakan grafik ataupun menggunakan cara penyelesaian tabel matriks.

\section{Rotasi}

Ketiga, cara penggunaan media pembelajaran Blabak Trarerodi pada subbab rotasi. Tidak lupa untuk mengganti judul sub-bab dan latihan soal agar lebih mudah dalam proses penyelesaiannya.

Setelah membuat soal dan menerapkannya ke dalam media, langkah selanjutnya kita menyiapkan paku mading untuk menandai titik yang diketahui di soal. Setelah itu membuat lingkaran (dengan diameter sesuai keinginan) dan 
menancapkan lingkaran itu pada media, lingkaran ini digunakan untuk memutar suatu titik sesuai dengan sudut yang diketahui di soal. Langkah selanjutnya yaitu, meletakkan paku mading tersebut pada grafik kartesius yang ada pada media sesuai dengan titik yang diketahui di soal yaitu $A(2,1)$.

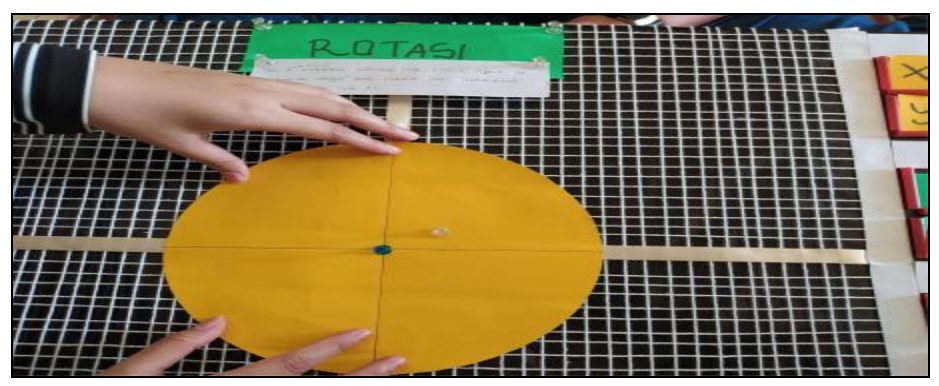

Gambar 7. Media Trarerodi Digunakan untuk Materi Rotasi

Kemudian, memutar paku yang telah ditancapkan sesuai dengan yang diketahui pada soal yaitu sejauh $90^{\circ}$ berlawanan arah dengan jarum jam. Dengan demikian dapat diketahui hasil dari titik A $(2,1)$ dirotasi sejauh $90^{\circ}$ berlawanan arah jarum jam yaitu $(-1,2)$.

Selain menggunakan grafik, dapat juga menyelesaikan soal rotasi dengan menggunakan matriks yang berada di sebelah kanan grafik. Langkah pertama yaitu, menentukan nilai dari sudut, titik pusat $\mathrm{O}(\mathrm{a}, \mathrm{b})$ dan titik koordinat $\mathrm{A}(\mathrm{x}, \mathrm{y})$ yang sudah diketahui di dalam soal, kemudian menyiapkan kertas berbentuk persegi dengan ukuran sesuai matriks yang sudah disiapkan dalam media tersebut.

Setelah membuat potongan kertas berbentuk persegi, langkah selanjutnya yaitu menuliskan nilai sudut, nilai titik koordinat, dan nilai titik pusat yang sudah diketahui pada setiap kertas, misalnya pada titik koordinat $\mathrm{A}(\mathrm{x}, \mathrm{y})$, dapat dituliskan pada 2 potongan kertas, kertas pertama berisi titik koordinat $\mathrm{x}$, sedangkan potongan kertas kedua berisi titik koordinat $y$, dan ulangi cara berikut saat menuliskan nilai titik pusat dan nilai sudut pada potongan kertas yang telah disediakan.

Langkah selanjutnya yaitu menempelkan potongan kertas yang sudah ditulis dengan nilai- nilai tersebut pada matriks yang telah disiapkan pada media pembelajaran Blabak Trarerodi yang berada di sebelah kanan dari grafik Blabak Trarerodi . Kemudian tentukan hasil dari perhitungan rotasi diatas. Langkah terakhir yaitu, pastikan bahwa nilai- nilai tersebut telah masuk sesuai dengan tempat yang telah disediakan pada media pembelajaran Blabak Trarerodi. 


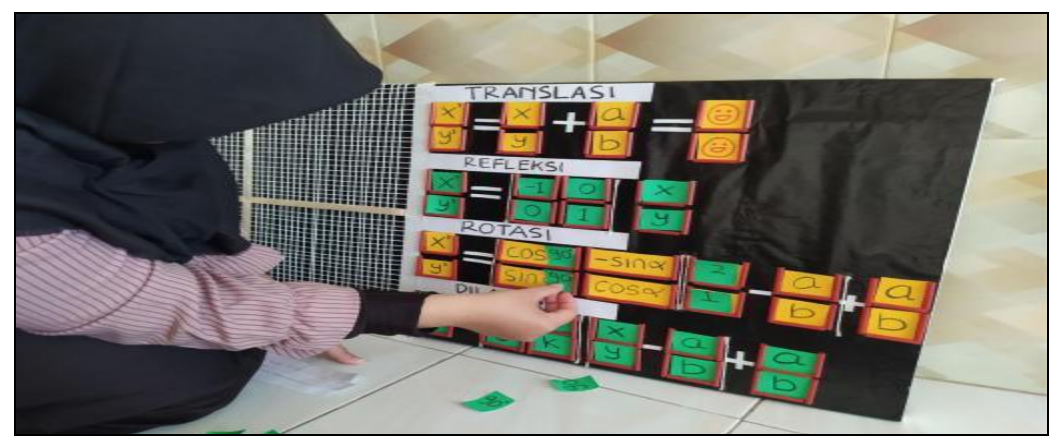

Gambar 8. Memperagakan Media Tratrerodi

\section{Dilatasi}

Keempat, cara penggunaan media pembelajaran Blabak Trarerodi pada sub-bab dilatasi. Langkah pertama, tentu tidak lupa untuk mengganti judul dan latihan soal pada media. Hal ini bertujuan agar lebih mudah dalam melihat kembali butir soal yang ditanyakan dan akan diselesaikan menggunakan media Blabak Trarerodi.

Setelah menyiapkan butir soal pada media Trarerodi pada sub-bab dilatasi, langkah selanjutnya adalah menyiapkan paku sejumlah titik yang diminta pada soal. Pada soal dilatasi ini diketahui titik $A(3,1)$ hal ini berarti ada satu titik sehingga membutuhkan 1 paku berwana kuning yang ditancapkan di mading untuk menandai titik awal tersebut.

Selain itu di dalam soal dijelaskan bahwa titik $A(3,1)$ didilatasi terhadap titik pusat $O(0.0)$ dengan faktor skala -1 . Jika titik $\mathrm{A}(x, y)$ didilatasikan terhadap titik pusat $\mathrm{O}(0.0)$ dengan faktor skala $\mathrm{k}$, maka bayangan yang dihasilkan adalah $\mathrm{A}^{\prime}$ $\left(x^{\prime}, y^{\prime}\right)$ dengan $x^{\prime} \mathrm{k} x$ dan $y^{\prime} \mathrm{k} y$. Oleh karena itu, kami menggunakan paku yang berbeda dari titik awal yaitu pakuberwarna merah pada bayangan titik tersebut. Hasil bayangan dari butir soal dilatasi diatas adalah $A^{\prime}(3,1)$.

Setelah mengetahui hasil bayangan, langsung saja tandai titik $A^{\prime}(-3,-1)$ dengan warna paku berbeda dengan tujuan agar terlihat perbedaannya antara titik awal dengan hasil bayangan titik yang dihasilkan. Dengan demikian, dapat kita ketahui bahwa hasil dilatasi dari titik $A(3,1)$ terhadap titik pusat $O(0.0)$ dengan faktor skala -1 adalah $A^{\prime}(-3,-1)$.

Selain menggunakan cara grafik, dapat dilakukan juga dengan menggunakan media tabel matriks seperti di papan Trarerodi sebelah kanan grafik. Langkah pertama yang harus dilakukan adalah melihat titik $\mathrm{A}(3,1)$ yang didilatasi terhadap pusat $\mathrm{O}(0.0)$ dengan faktor skala - 1 sehingga nilai $a$ dan $b$ pada matriks bernilai 0 . Kemudian isikan angka -1 pada kotak $k$, angka 3 pada kotak $x$, 
dan angka 1 pada kotak $y$. Langkah selanjutnya adalah mengoperasikan soal seperti biasanya sehingga diperolah hasil bayangan titik $A^{\prime}(-3,-1)$. Hal ini membuktikan bahwa titik $\mathrm{A}(3,1)$ yang didilatasi terhadap pusat $\mathrm{O}(0.0)$ dengan faktor skala -1 menunjukkan hasil yang sama jika menggunakan grafik ataupun menggunakan cara penyelesaian tabel matriks.

Demikian tata cara penggunaan media pembelajaran matematika yaitu Blabak Trarerodi dengan pembahasan materi transformasi geometri meliputi subbab translasi, refleksi, rotasi, dan dilatasi.

\section{Simpulan}

Media Blabak Trarerodi dalam pembelajaran matematika memiliki arti sebuah papan yang didesign sedemikian rupa sehingga membentuk sebuah susunan proses penyelesaian terkait materi transformasi geometri yaitu translasi, refleksi, rotasi, dan dilatasi. Media Blabak Trarerodi memiliki keunggulan diantaranya adalah cara pembuatannya yang mudah dan memperjelas sistematika proses pengerjaan transformasi geometri, media ini mengemas pembelajaran dengan praktis, kreatif, dan inovatif, media dapat digunakan secara berulang-ulang pada tahun ajaran berikutnya, dapat digunakan di dalam atau di luar ruangan karena papan Trarerodi ini tidak menggunakan arus listrik, serta bahan yang digunakan untuk pembuatan media pembelajaran ini relatif murah. Berdasarkan hasil yang diberikan oleh validator, bahwa media yang dibuat sudah cukup baik untuk dapat digunakan dalam pembelajaran. Walaupun hasil sudah baik, namun ada beberapa bagian yang perlu diperbaiki. Hal ini dihubungan dengan per materi yang disampaikan. Setelah proses perbaikan yang dilakukan, sebaiknya langsung diujicobakan pada siswa yang sedang belajar tentang materi ini. Dari hasil uji coba ini diharapkan memperoleh masukan secara langsung dari pengguna media yang telah dibuat.

\section{Daftar Pustaka}

Anwar, S., \& Anis, M. B. (2020). Pengembangan Media Pembelajaran Matematika Berbasis Adobe Flash Profesional pada Materi Sifat-Sifat Bangun Ruang. Jurnal Pendidikan Matematika (Kudus), 3(1), 83-98.

Auliya, N. N. F. (2018). Pengembangan Pembelajaran Berbasis Multimedia Interaktif Menggunakan Adobe Flash Cs. 6 dalam Pembelajaran Matematika 
Pada Kelas X Materi Pokok Pertidaksamaan Satu Variabel. Jurnal Pendidikan Matematika (Kudus), 1(1).

Cahyadi, R. A. H. (2019). Pengembangan Bahan Ajar Berbasis ADDIE Model. HALAQA: Islamic Education Journal, 3(1).

Dinak, M. R. (2016). Penerapan Transformasi Geometri untuk Visualisasi Objek Maya Berbasis Android. Disertasi. UIN Maulana Malik Ibrahim.

Fakhrurrazi. (2018). Hakikat Pembelajaran yang Efektif. Jurnal At-Tafkir, 11(1). 8599.

Fitria, Uce, L., \& Hayati, Z. (2019). Penggunaan Media Papan Raba untuk Meningkatkan Kemampuan Mengenal Lambang Bilangan pada Anak Kelompok A Di TK Alifba 1 Iskandar Muda Banda Aceh. UIN Ar-Raniry.

Irmawati, D. A. (2020). MEDIA PEMBELAJARAN MATEMATIKA: Cara Gembira Belajar Matematika. Pemeral edukreatif.

Izah, S. J., \& Malasari, P. N. (2021). Studi Etnomatematika: Masjid Sunan Bonang dalam Pembelajaran Geometri. CIRCLE: Jurnal Pendidikan Matematika, 1(1), 44-58.

Jamil, A. F. (2019). Geometri Transformasi (Vol. 1). Malang: UMMPress.

Januszewski, A., \& Molenda, M. (2008). Technology: A Definition With Commentary. New York: Lawrence Erlbaum Associates.

Jufri, D. H. . (2016). Teknik Analisis dalam Komponen Pembelajaran. Jurnal UIN Syarif Hidayatullah Jakarta, 5(2).

Khoirunnisa, P. H., \& Malasari, P. N. (2021). Analisis Kemampuan Berpikir Kritis Matematis Siswa Ditinjau dari Self Confidence.JP3M (Jurnal Penelitian Pendidikan dan Pengajaran Matematika), 7(1), 49-56.

Malasari, P. N., Herman, T., \& Jupri, A. (2019). Kontribusi Habits of Mind Terhadap Kemampuan Literasi Matematis Siswa pada Materi Geometri.Jurnal Pendidikan Matematika (Kudus), 2(2), 153-164.

Malasari, P. N., Herman, T., \& Jupri, A. (2020). Inquiry Co-Operation Model: An Effort to Enhance Students' Mathematical Literacy Proficiency. JTAM (Jurnal Teori dan Aplikasi Matematika), 4(1), 87-96.

Masitoh, \& Habudin. (2018). Pengembangan Media Pembelajaran Papan Berpaku Untuk Meningkatkan Pemahaman Konsep Luas Bangun Datar. Ibtida'i, 5(1).

Miftah, M. (2013). Fungsi dan Peran Media Pembelajaran Sebagai Upaya Peningkatan Kemampuan Belajar Siswa. Jurnal KWANGSAN, 1(2). 
Oktaviani, T. D., Andari, K. D. W., \& Bua, A. T. (2020). Pengembangan Media Papan Baca Pintar Berbasis Literasi Sains Di SDN 011. JURNAL PENA KARAKTER: Jurnal Pendidikan Anak Dan Karakter, 2(2).

Putra, B. S., Hunaifi, A. A., \& Saidah, K. (2018). Pengembangan Media Papan Tempel pada Pembelajaran Materi Daur Hidup Hewan Siswa Kelas 4 Sekolah Dasar Tahun Ajaran 2017/2018. Universitas Nusantara PGRI Kediri.

Rahayu, P., \& Paksi, H. P. (2018). Pengembangan Media Papan Flanel Berputar untuk Membantu Guru Memahamkan Materi Dampak Globalisasi Terhadap Siswa SD. JPGSD, 6(4).

Razaq, A. (2009). Strategi dan Model Pembelajaran Sejarah. Cendekia Insani.

Richey, R. C., \& Klein, J. (2007). Design and Development Research: Methods, Strategies, and Issues. Lawrence Erlbaum Associates, Publishers.

Roebyanto, G. (2014). Geometri Pengukuran dan Statistik. Malang: Penerbit Gunung Samudera.

Sakti, H. G., \& Farhan, H. (2020). Pengaruh Media Papan Flanel Terhadap Minat Belajar Siswa. Jurnal Paedagogy: Jurnal Penelitian Dan Pengembangan Pendidikan, 7(3).

Sugiyono. (2014). Metode Penelitian Kuantitatif, Kualitatif, dan R\&D. Bandung: Alfabeta.

Surur, A. M. (2018). Peningkatan Kemampuan Khatabah (Public Speaking Skill) Santri Ma'had Darul Hikmah IAIN Kediri. Ijaz Arabi Journal of Arabic Learning, 1(2).

Surur, A. M. (2020a). Ragam Strategi Pembelajaran Dilengkapi dengan Evaluasi Formatif. CV. AA. Rizky.

Surur, A. M. (2020b). Thorndike's Learning Theory Application for Improving Creative Thinking Abilities And Publications. The Atlantis Press Proceedings.

Surur, A. M., \& Cholifah, K. N. (2018). Good Governance Pada Kepengurusan Pondok Pesantren Putri Al-Amien. Al-Tadzkiyyah: Jurnal Pendidikan Islam, 9(2), 261-274.

Surur, A. M., Rais, P., \& Habib. (2017). The Application Program of The Preparation of The Syllabus and Learning Implementation Plan (RPP) 2013 Curriculum on Teachers Madrasah Ibtidaiyah. Proceedings International Conference on Islamic Education (ICIED), 2(1), 246-253. 
Tafonao, T. (2018). Peranan Media Pembelajaran Dalam Meningkatkan Minat Belajar Mahasiswa. Jurnal Komunikasi Pendidikan, 2(2).

Zakiyah, M., \& Malasari, P. N. (2021). Etnomatematika: Identifikasi Batik Bakaran Berdasarkan Konsep Geometri Transformasi.J-PiMat: Jurnal Pendidikan Matematika, 3(1), 287-294. 